original Indian inhabitants and the various invading Mongolian armies. (2) Both Pashtun and Baluch are Aryan or have Aryan roots and thus have more common links with Iranian stock. ${ }^{1}$ (3) The Pashtun in the Jinnah sample are not representative, as obviously they were taken from the million or so people working in the factories of Karachi. If one has to validate the argument a survey at Peshawar or Jalalabad would be more realistic.

London SE9

G Y ZAKARIA

1 Caroe, O, The Pathans (550 BC-AD 1957). London, Macmillan, 1964

\section{Cervical diameter after suction termination of pregnancy.}

SIR,-In their study of cervical diameters following suction termination of pregnancy Mr F D Johnstone and his colleagues (10 January, p 68) observed that dilatation of the cervix beyond $10 \mathrm{~mm}$ at the time of suction termination of pregnancy results in a greater frequency of abnormally high cervical diameters when measured subsequently. As pointed out by the authors, measurement of cervical dilatation has limitations, particularly as cervical incompetence is likely to be a disorder of function rather than anatomy. However, their results support previously reported" findings that "something happens" when cervices are dilated beyond $9-11 \mathrm{~mm}$ in the pregnant and non-pregnant state.

In a series of in-vivo and in-vitro studies of 38 cervices dilatation was achieved with a cone-shaped dilator under standard conditions and the applied forces recorded. Sudden loss of resistance occurred on over $50 \%$ of occasions when dilatation exceeded $11 \mathrm{~mm}$ diameter. A similar loss of resistance during the course of clinical cervical dilatation is frequently experienced by many gynaecologists and may represent the yielding or rupture of tissue. By the use of mechanical longitudinal vibration it was possible to achieve greater cervical dilatation at lower values of applied force.

More work will be necessary to determine the clinical importance of these findings, but the frequency with which damage to cervical tissue seems to occur at dilatations over $11 \mathrm{~mm}$ is disturbing. In order to reduce the morbidity of dilatation and curettage it is likely that more efficient methods of dilating the cervix will need to be developed. The use of vibration may prove to be one such method. Meanwhile we would advocate the wider use of Vabra curettage for endometrial biopsy and support the recommendation of $\mathrm{Mr}$ Johnstone and his colleagues that dilatation of the cervix should whenever possible not exceed $10 \mathrm{~mm}$.

Department of Medical Physics,

Martin M Black University of Sheffield

Brian Alderman

Department of Obstetrics and Gynaecology,

University of Liverpool

${ }^{1}$ Black, M M, et al, in Clinics in Obstetrics and Gynaecology, ed J M Beazley, vol 2, no 1 . London,

\section{GMC election}

SIR,-Along with my fully registered medically qualified colleagues I have recently received a ballot paper from the General Medical
Council for the purpose of electing eight members to the Council. The ballot paper gives virtually no useful information to voters. For readers of the $B M F$, some information on the eight BMA-sponsored candidates is available. This leaves a considerable number of candidates who remain just short of anonymous, although standing for election to one of the profession's most powerful controlling bodies.

As I feel sure that many electors must find this unsatisfactory, I propose that in future years the GMC invite all candidates to make a statement about themselves indicating not only their medical achievements but also the sort of policies they would advocate if they were elected to the GMC. In addition, they should have to declare their membership of any political party or organisation (Conservative, Labour, Liberal, Communist, Fascist, etc) or similar body now that medicine is no longer free from much political interference; failure to make such a declaration or the making of an incorrect one should result in their candidature being invalid.

Is there any support for my proposal ?

Department of Physiology,

University of Sheffield

\section{Cover out of hours}

SIR,-With reference to the last paragraph of your excellent leading article on this subject (27. March, p 732), I have long maintained that the educational value of the extensive and concentrated experience to be gained by working for a deputising or emergency service should, not would, be enhanced by involving all those involved in training for the general practice of today in the day-to-day operation of these services.

All concerned, be they trainers, trainees, course organisers, lecturers, service operators, or-not least-patients would benefit in both the short and the long term.

Leeds

M DALES

\section{Improving the hospital service?}

SIR,-Few would dispute Dr J F Murray' thesis (28 February, p 507) that there is room for improvement in hospital managemen structure. It is regrettable, therefore, that his arguments are vague and that he gives insufficient evidence to justify his conclusions.

It is asserted that a Dutch hospital"managed its own affairs with 19 people" compared with a British hospital which "employed 49." There is no attempt to define what staff are included in this comparison.

Secondly, Dr Murray writes that "all Dutch nurses are trained to the level of a British SRN." Is it implied that this is desirable? If so, how is the use of highly skilled professional staff to carry out semi-skilled tasks justified ?

The accompanying organisation charts are so misleading as to cast doubt on the author's objectivity. The Dutch chart includes seven boxes compared with 11 in the British model. However, the latter includes both the district management team and a "district team of officers," "public health," "general practitioners," and "joint consultative committee." Without these four invalid items the number is seven, as in Holland.
In view of such nebulous argument it is difficult to learn anything of value from the article. This is especially regrettable at this moment, when constructive criticism of the management of hospitals would be welcomed by the majority of administrators.

Peter A Hill

Southampton

\section{Distinction awards}

SIR,-Dr L C Hurst (13 March, p 652), commenting on our recent paper (28 February, p 536), mentions important issues which were examined in our previous paper (18 January 1975, p 162). Briefly, the impossibility of arranging 12000 consultants in an agreed ranking order forces committee members into the dubious compromises of a quota system, prejudged for different sectors, officially disclaimed but amply confirmed by information from several sources. We think that it is impossible to have a discretionary system of awards that is fair, but that the present system is worse than necessary.

Policy statements do not appear to tally with the facts; official figures are scanty, fragmented, and buried. Committees are overloaded with certain specialties and the dependence on award-holders for this work must lead to bias and error from many factors. (It must be a matter of interest to all 12000 consultants to ask how many minutes of the top committee's time was available for each of the 794 awards they allocated in 1974.) Of course talent is unequally distributed, but the distribution of new awards seems not so much the result of recognising new talent but rather the conservation of prejudged quotas. The Awards Committee invited three times as many nominations for $\mathrm{C}$ awards from London teaching hospitals in 1973 as for non-teaching hospital consultants (per head).

It is officially claimed that serious errors are rare and will be corrected when ascertained. As a test case the situation at the Tavistock Clinic seems incompatible with that contention. Dr Hurst writes, "the Tavistock Clinic does not appear to have its fair share of distinction awards and on the face of it this would appear to be unreasonable." Over two years we gave the Awards Committee a great deal of information. As a measure of the clinic's standing, 11 London consultants (two of them at teaching hospitals) applied for a recent vacancy here. Nevertheless the awards allocated, twice revised, rest well below the national average, under half the average for teaching hospitals, and close to that for all psychiatrists.

Our indictment has raised no word in defence or reply, although publicised in The Times, the Sunday Times, and the local press. The secrecy over the system contrasts with the ready display of peerages and prestigious appointments. Secrecy is supported mainly by those consultants who benefit from the system but opposed by those without awards (CCHMS figures). This suggests what most consultants think about the way awards are distributed. We think the system should be scrapped; it degrades the profession.

S BOURNE

Tavistock Clinic, P BRUGGEN 